\title{
Pengaruh E-Filing, Kualitas Pelayanan, Audit dan Pemeriksaan Perpajakan dan Biaya Kepatuhan Pajak Terhadap Kepatuhan Wajib Pajak
}

\author{
Nena Suyati ${ }^{1, *}$, Sugiharto $^{2}$ \\ ${ }^{1}$ KPP Pratama Bekasi Selatan; Jl Cut Mutia No 125 Margahayu, Bekasi Timur, (021) \\ 88346441; e-mail: nena.dgt903@gmail.com \\ ${ }^{2}$ KPP Pratama Jakarta Sawah Besar Dua; Jalan Gunung Sahari Raya, RT.12/RW.4, Kota \\ Jakarta Pusat, (021) 6244155; e-mail: sugiharto.dgt903@gmail.com \\ * Korespondensi: e-mail: nena.dgt903@gmail.com
}

Submitted: 10/05/2021; Revised: 17/05/2021; Accepted: 21/05/2021; Published: 27/05/2021

\begin{abstract}
To improve the quality of tax services, the government issued an e-filing policy. Also, tax audits and tax compliance fees are also strengthened in order that taxes as the main income of the state can be increased. In particular, at this time the issue of non-compliance with taxes through tax avoidance and even tax evasion is increasingly widespread. Therefore, this study aims to examine the level of tax compliance based on the above aspects. This study uses quantitative analysis. The sample was gathered on 100 taxpayers in the Bekasi Selatan KPP environment. The sample was chosen based on accidental sampling, and questionnaire was processed using multiple linear regression techniques in SPSS software. The regression results show that the implementation of e-filing, service quality, audit and tax audit, and tax compliance costs have a positive and significant effect on taxpayer compliance. In addition, several variables need attention, including the application of e-filing of the ITE law and audits and tax audits related to the ethics and professionalism of tax examiners.
\end{abstract}

Keywords: Multiple Linear Regression, KPP Pratama Bekasi Selatan, Taxpayer Compliance, SPSS, Accidental Sampling

\begin{abstract}
Abstrak
Untuk meningkatkan kualitas pelayanan pajak, pemerintah mengeluarkan kebijakan e-Filing. Selain itu, audit dan pemeriksaan perpajakan dan biaya kepatuhan pajak juga diperkuat agar pajak sebagai pendapatan utama negara dapat ditingkatkan. Apalagi saat ini isu ketidakpatuhan terhadap pajak lewat penghindaran bahkan penggelapan pajak kian marak. Oleh karena itu penelitian ini bermaksud meneliti tingkat kepatuhan pajak berdasarkan aspekaspek di atas. Sampel dilakukan terhadap 100 orang wajib pajak di lingkungan KPP Pratama Bekasi Selatan. Dengan sampel yang dipilih berdasarkan accidental sampling, kuesionar diolah menggunakan teknik regresi linear berganda. Hasil regresi menunjukan penerapan e-filing, kualitas pelayanan, audit dan pemeriksan perpajakan, dan biaya kepatuhan pajak berpengaruh positif dan signifikan pada kepatuhan WP OP. Selain itu, beberapa variabel perlu mendapat perhatian antara lain penerapan e-filing undang-undang ITE dan audit dan pemeriksaan pajak terkait etika dan profesionalisme pemeriksa pajak.
\end{abstract}

Kata kunci: Regresi Linear Berganda, KPP Pratama Bekasi Selatan, Kepatuhan Wajib Pajak, SPSS, Accidental Sampling 


\section{Pendahuluan}

Seiring dengan perkembangan teknologi informasi, pemerintah memberlakukan konsep pengelolaan pajak berbasis daring yang dikenal dengan istilah e-filing. Hal ini bermaksud untuk meningkatkan tingkat kepatuhan para wajib pajak dengan harapan meningkatkan pemasukan pajak (PPh, PPN, PBB dan BPHTB) (Kementerian Keuangan Republik Indonesia, 2020). Penelitian-penelitian mengenai tingkat kepatuhan sudah banyak dilaksanakan di beberapa Kantor Pelayanan Pajak di tanah air (Akhmadi, 2017; Arifin \& Syafii, 2019; Rara Susmita \& Supadmi, 2016; Suharsono, 2018; Tumuli, Sondakh, \& Wokas, 2016).

Variabel-variabel yang mendukung kepatuhan wajib pajak sudah banyak diteliti, antara lain: penerapan e-filling, sanksi pajak, sikap fiskus, lingkungan pajak, pengetahuan akan peraturan pajak, persepsi atas efektifitas system perpajakan, kualitas pelayanan, audit dan pemeriksaan pajak, dan lain-lain yang masih terus diteliti.

Penelitian oleh (Tumuli et al., 2016) dan (Akhmadi, 2017) meneliti pengaruh e-filling terkait peningkatan wajib pajak di KPP Pratama Manado dan KPP Pratama Jakarta Taman Sari Dua. Terjadi peningkatan pelaporan pajak dibanding periode manual. Namun hasil evaluasi dijumpai beberapa masalah dalam penggunaan e-filling, seperti terlalu lama pengguna membuka browser, koneksi jaringan yang lambat, dan hal-hal lain terkait perilaku yang cenderung mengisi mendekati tenggat waktu yang ditentukan.

Penelitian oleh (Arifin \& Syafii, 2019) menunjukan hasil sebaliknya lewat survey yang dilakukan di KPP Pratama Medan Polonia. Dengan analisa kuantitatif, lewat beberapa uji (uji validitas dan reliabilitas) terhadap variabel-variabel yang mempengaruhi (penerapan e-filling, penerapan e-billing, kepatuhan pajak dan wajib pajak) tidak ditemukan peningkatan yang signifikan. Namun $97 \%$ variabel perlu diteliti lebih lanjut, terutama di wilayah lain.

Sementara itu hasil penelitian di kota Padang menunjukan pelayanan dan sanksi berpengaruh positif terhadap kepatuhan para wajib pajak (Pratama \& Mulyani, 2019). Sementara itu biaya kepatuhan pajak (tax compliance costs) berpengaruh negatif terhadap kepatuhan wajib pajak.

Kebanyakan penelitian menggunakan analisa kuantitatif lewat regresi linear berganda dengan beberapa uji validitas. Penelitian ini pun menggunakan analisa kuantitatif tetapi dengan tambahan pendekatan yuridis normatif. Penelitian ini bermaksud menjawab beberapa pertanyaan penelitian antara lain: 1) Apakah e-filling mempengaruhi kepatuhan WP OP?, 2) Apakah audit dan pemeriksaan pajak berperan terhadap kepatuhan WP OP?, 3) Apakah kualitas pelayanan berpengaruh terhadap kepatuhan WP OP?, dan 4) Apakah biaya kepatuhan pajak berpengaruh terhadap kepatuhan WP OP?

\section{Metode Penelitian}

Penelitian ini menggunakan metode kuatitatif dengan regresi linear berganda terhadap variabel-variabel yang mempengaruhi kepatuhan wajib pajak orang pribadi (WP OP). Survey 
dilakukan terhadap 100 responden KPP Pratama Bekasi Selatan. Software SPSS digunakan untuk mengolah data dan menguji validitas dan reliabilitas.

Wawancara dan studi literatur diperlukan mengingat artikel juga menerapkan metode yuridis normatif berkaitan dengan e-filling dan audit \& pemeriksaan pajak sebagai variabel.

\subsection{E-Filing}

Dalam rangka modernisasi pelayanan perpajakan, pemerintah menyelenggarakan proses pelaporan SPT dengan menggunakan e-Filing yang berbasis elektronik. Secara resmi diumumkan dalam Keputusan Dirjen pajak No. Kep-88/PJ/2004 yand dikeluarkan pada tanggal 21 Mei 2004. Harapannya akan terjadi peningkatan kepatuhan WP OP karena dapat melaksanakan proses pelaporan SPT di manapun dan kapan pun.

\subsection{Kualitas Pelayanan Pajak}

Kualitas pelayanan pajak sering disebut pelayanan fiskus. Fiskus yang merupakan petugas pajak akan membantu, mengurus, menyiapkan segala hal yang diperlukan seseorang wajib pajak dalam kegiatan perpajakannya. Pelayanan pajak akan dijadikan salah satu variabel penentu kepatuhan wajib pajak dalam artikel ini.

\subsection{Audit \& Pemeriksaan Pajak}

Audit dan pemeriksaan pajak tidak lepas dari hasil reformasi undang-undang perpajakan sejak tahun 1984 dimana prinsip asesmen mandiri menggantikan assesmen oleh petugas pajak (official assessment) (Budileksmana, 2001). Pelaksanaannya melibatkan beberapa aktivitas terkait antara lain: penelitian, pemeriksaan, dan penyidikan pajak.

Mengacu pada UU no. 16 tahun 2000, penelitian berisi kegiatan dalam menilai kelengkapan wajib pajak dalam mengisi SPT (penulisan dan perhitungan). Tahap pemeriksaan dilakukan jika ditemukan kesalahan dan juga hal-hal lain sesuai dengan Peraturan Menteri Keuangan tahun 1994. Secara rinci, pemeriksaan pajak berisi aktivitas-aktivitas mencari, mengumpulkan, dan mengolah data maupun keterangan lain yang semua dilakukan dalam rangka mengawasi kepatuhan wajib pajak dengan prinsip pemeriksaan kepatuhan (Compliance Audit).

\subsection{Biaya Kepatuhan Pajak}

Biaya kepatuhan pajak (tax complance costs) merupakan kewajiban perpajakan oleh wajib pajak dalam rangka ikut mendukung pembangunan bangsa dengan harapan dalam pemenuhannya dilakukan dengan sukarela (Pratama \& Mulyani, 2019). Secara teknis biaya kepatuhan pajak adalah biaya yang dikeluarkan oleh wajib pajak baik secara fisik maupun psikis dalam memenuhi kewajiban pajaknya.

Dalam pelaksanaanya survey menggunakan skala 1 sampai 5 . Dengan kategori 1, 2, 3, 4 dan 5 berturut-turut menyatakan 'sangat tidak setuju', 'tidak setuju', 'ragu-ragu', 'setuju', dan 'sangat setuju'. Variabel-variabel di atas dikonversi menjadi variabel $\mathrm{x}$ dengan $\mathrm{x} 1, \mathrm{x} 2, \mathrm{x} 3$, dan $\mathrm{x} 4$ menyatakan e-filling, kualitas pelayanan, audit dan pemeriksaan pajak, dan biaya kepatuhan pajak. 


\section{Hasil dan Pembahasan}

Untuk menjawab pertanyaan penelitian diperlukan analisa dengan mengolah data hasil survey. Sebelumnya data perlu diuji validitasnya.

\subsection{Uji Kualitas Instrumen Data}

Beberapa uji validatas dapat digunakan antara lain: uji normalitas, uji multikolinearitas, uji heteroskedastisitas. Karakteristik responden hasil survey dapat dilihat dalam tabel 1.

Tabel 1. Uji Validitas

\begin{tabular}{llcc}
\hline No & Keterangan & Jumlah (orang) & Persentase \\
\hline 1 & Jenis Kelamin & & \\
& 1. Laki-laki & 43 & $43 \%$ \\
& 2. Perempuan & 57 & $57 \%$ \\
\hline 2 & Usia Saat Survey & & \\
& 1. $\quad 31-40$ & 47 & $47 \%$ \\
& 2. $\quad 41-50$ & 31 & $31 \%$ \\
& 3. >50 & 22 & $22 \%$ \\
\hline 3 & Pendidikan Terakhir & & \\
& 1. SMA/sederajat & 37 & - \\
& 2. Diploma & - & $51 \%$ \\
& 3. Sarjana & 51 & $12 \%$ \\
\hline & 4. Pascasarjana & 12 & $100 \%$
\end{tabular}

Sumber: Hasil Pengolahan Data (2021)

Hasil survey dapat dideskripsikan sebagian responden adalah wanita berusia di bawah 50 tahun dengan tingkat pendidikan mayoritas SMA dan Sarjana.

\subsection{Hasil Uji Validitas}

Hasil uji validitas menggunakan pearson product-moments. Besarnya df diperoleh $\mathrm{n}-2=$ 98 dengan $n$ jumlah sampel (100 orang). Nilai $r$ hasil perhitungan juga harus dibandingkan dengan $r$ dari tabel, dimana pertanyaan memenuhi syarat jika $r$ hitung lebih besar dari $r$ tabel. Tabel 2 memperlihatkan hasil uji validitas.

Tabil 2. Hasil Uji Validitas

\begin{tabular}{lllllll}
\hline Variabel & Item & $\begin{array}{l}\text { Koefisien } \\
\text { Korelasi }\end{array}$ & $\begin{array}{l}\text { Nilai } \\
\text { tabel }\end{array}$ & $\begin{array}{l}\text { Nilai R } \\
(\mathrm{n}=100)\end{array}$ & Tabel \\
\hline Tersedianya E-Filing & Q1 & 0,218 & 0,163 & Valid & \\
& Q2 & 0,575 & 0,163 & Valid & \\
& Q3 & 0,757 & 0,163 & Valid & \\
& Q4 & 0,707 & 0,163 & Valid & \\
& Q5 & 0,775 & 0,163 & Valid & \\
\hline Kualitas Pelayanan Pajak & Q1 & 0,450 & 0,163 & Valid \\
& Q2 & 0,426 & 0,163 & Valid \\
& Q3 & 0,717 & 0,163 & Valid & \\
& Q4 & 0,386 & 0,163 & Valid & \\
\hline
\end{tabular}




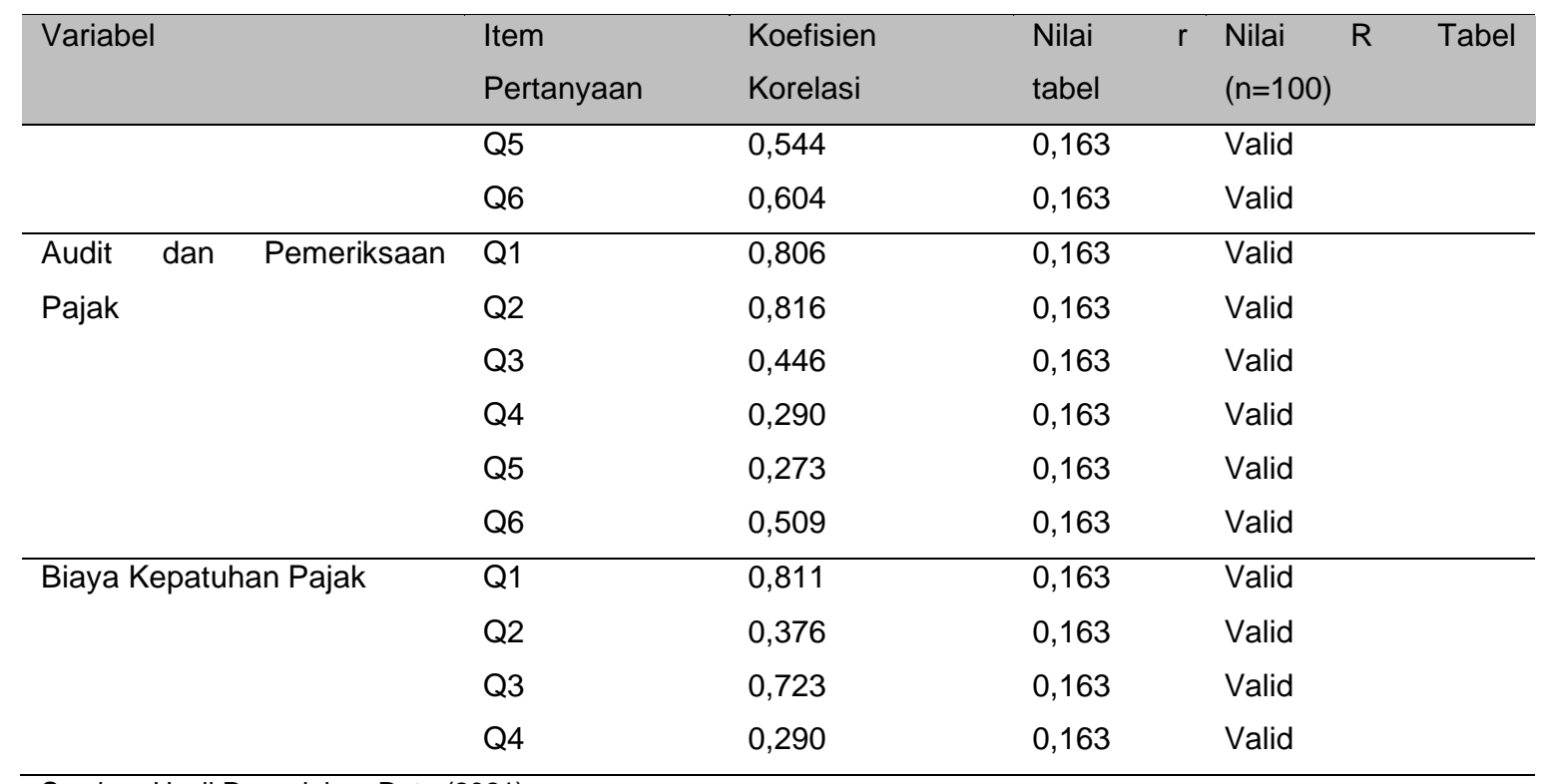

Sumber: Hasil Pengolahan Data (2021)

\subsection{Hasil Uji Reliabilitas}

Uji reliabilitas dalam penelitian ini menggunakan Alhpa Cronbach. Tabel 3 memperlihatkan hasil perhitungan uji reliabilitas.

Tabel 3. Hasil Uji Reliabilitas

\begin{tabular}{llll}
\hline Variabel & Cronbach's Alpha & Jumlah Pertanyaan & Keterangan \\
\hline Tersedianya E-Filing & 0,648 & 5 & Reliabel \\
\hline Kualitas Pelayanan Pajak & 0,612 & 6 & Reliabel \\
\hline Audit dan Pemeriksaan Pajak & 0,464 & 6 & Reliabel \\
\hline Biaya Kepatuhan Pajak & 0,288 & 4 & Reliabel \\
\hline
\end{tabular}

Sumber: Hasil Pengolahan Data (2021)

Hasil uji reliabilitas menunjukan seluruh pertanyaan memiliki cronbach's alpha lebih besar dari 0,1638 . Dengan demikian variabel-variabel yang akan diukur dapat dikatakan reliabel.

\subsection{Hasil Uji Simulasi (Uji Statistik F)}

Hasil uji determinasi (adjusted $\mathrm{R}^{2}$ ) menunjukan $\mathrm{R}, \mathrm{R}$ Square, Adjusted $\mathrm{R}$ Square, dan Std. Error of the Estimate berturut-turut 0,254, 0,065, -0,007, 0,48997. Dengan demikian 0,48997 (49\%) merupakan variasi variabel-variabel independen dalam penelitian ini. Tabel 4 menunjukan hasil uji statistik F.

Tabel 4. Hasil Uji Statistik F

\begin{tabular}{llllll}
\hline Model & Sum of Square & Df & Mean Square & $F$ & Sig. \\
\hline Regressian Residual & 1,523 & 4 & 280,218 & 120,907 & 0.000 \\
& 22,086 & 92 & 2,240 & & \\
\hline Total & 23,610 & 99 & & &
\end{tabular}

Sumber: Hasil Pengolahan Data (2021) 
Predictors: penerapan e-filling, kualitas pelayanan, audit dan pemeriksaan pajak, dan biaya kepatuhan pajak.

Dependent Variable: Kepatuhan wajib pajak.

Nilai F hitung $(120,907)$ dengan signifikansi 0,000 menunjukan nilai lebih kecil dari 0,05 sehingga dapat disimpulkan bahwa penerapan e-filing, kualitas pelayanan, audit dan pemeriksaan pajak, dan biaya kepatuhan pajak berpengaruh pada kepatuhan wajib pajak. Model regresi yang terbentuk adalah:

$Y=2,86+0,01 X 1+0,08 X 2+0,072 X 3+0,035 X 4$

Dimana: $\mathrm{Y}=$ Kepatuhan Pajak; $\mathrm{X} 1=$ Penerapan E-Filing; $\mathrm{X} 2=$ Kualitas Pelayanan Pajak; X3=Audit dan Pemeriksaan Pajak; X4=Biaya Kepatuhan Pajak

\title{
Variabel Bebas: Kepatuhan Wajib Pajak
}

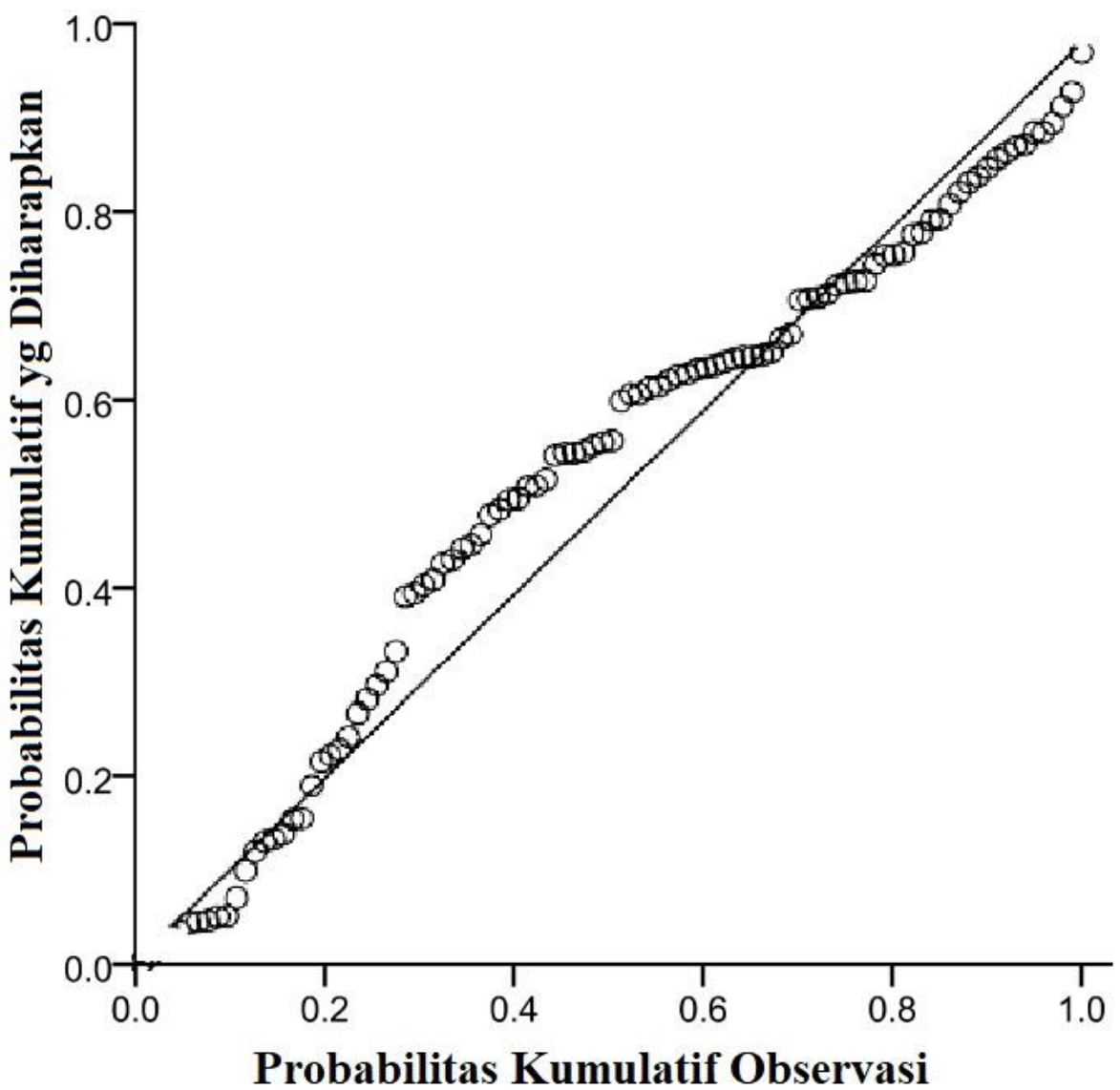

Sumber: Hasil Penelitian (2021)

\author{
Gambar 1. Hasil Regresi
}

\subsection{Permasalahan Pada Variabel-Variabel}

Beberapa variable berdasarkan hasil wawancara memiliki masalah. Untuk penerapan E-Filing banyak dijumpai masalah dalam koneksi, kemampuan masyarakat, dan karakter dalam mengisi di dekat tenggat waktu yang ditentukan. Hasil penelitian menunjukan penerapan $E$ Filing berpengaruh secara positif terhadap kepatuhan pajak, namun dalam sisi yuridis, harus mengikuti Pasal 19 undang-undang Informasi dan Transaksi Elektronik (ITE) dimana harus ada 
kesepakatan antara pengguna dan penyedia layanan, sehingga tidak bisa memaksakan untuk menerapkan e-filing.

Permasalahan pun muncul dalam variable audit dan pemeriksaan pajak. Sebagai ilustrasi, Gambar 2 memperlihatkan alur proes pemeriksaan pajak.

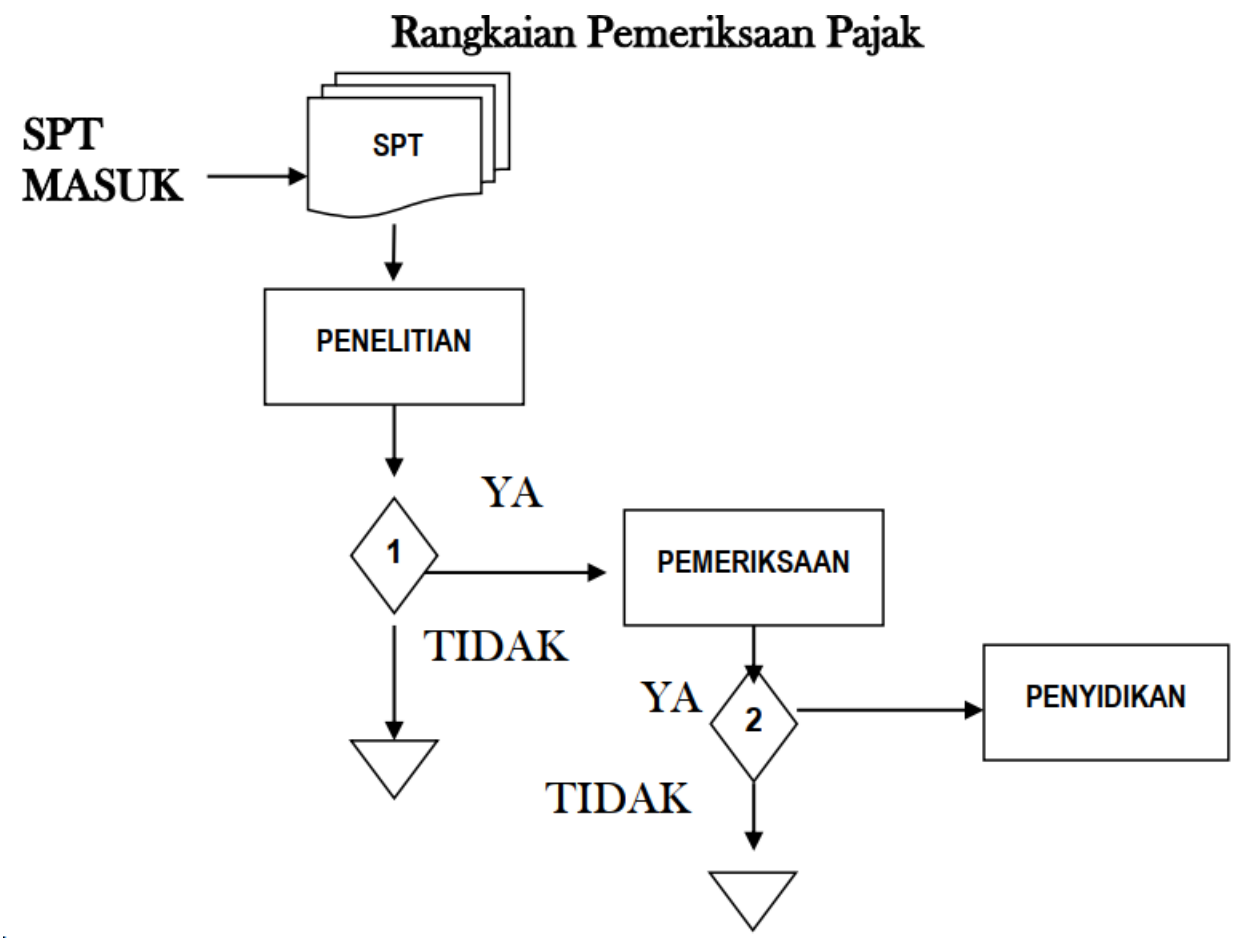

Sumber: (Budileksmana, 2001)

\section{Gambar 2. Diagram Alur Pemeriksaan Pajak}

Permasalah ditemukan di ketika proses pemeriksaan (penelitian, pemeriksaan, dan penyidikan) terutama dari sisi etika. Namun pedoman sudah dibuat, antara lain: 1) Memiliki keterampilan teknis, 2) jujur dan bertanggung jawab, terbuka, sopan, dan objektif, serta menghindari perbuatan tercela, 3) menggunakan keahlian dengan cermat dan seksama sesuai dengan keadaan yang sesungguhnya. Diberlakukannya peer review juga dapat meningkatkan kualitas dengan cara menilai kemampuan teknis pemeriksa pajak.

Biaya kepatuhan pajak memiliki pengaruh positif terhadap kepatuhan pajak. Hal ini sedikit berbeda dengan hasil penelitian di KPP Medan Polonia yang tidak menunjukan pengaruh positif (Arifin \& Syafii, 2019). Penelitian perlu dilakukan di tempat lain, khusus untuk variable ini terutama dari sisi perkotaan ataupun di luar perkotaan, mengingat biaya sedikit banyak berpengaruh terhadap WP OP.

\section{Kesimpulan}

Penelitian ini bermaksud melihat pengaruh variabel-variabel: penerapan e-filing, kualitas pelayanan pajak, audit dan pemeriksaan pajak serta biaya kepatuhan pajak terhadap kepatuhan WP OP. Hasil pengolahan data survey menunjukan keempat variabel tersebut berpengaruh positif terhadap kepatuhan WP OP. Hasil analisis yuridis dan normatif menunjukan 
masalah-masalah yang harus diselesaikan terhadap variabel-variabel pendukung kepatuhan pajak, misalnya memperkuat pemeriksa-pemeriksa pajak serta permasalahan penerapan efiling terkait undang-undang ITE.

\section{Ucapan Terima Kasih}

Terima kasih untuk para responden yang telah aktif mengisi kuesioner dan juga para reviewer atas masukan dan saran yang berharga.

\section{Daftar Pustaka}

Akhmadi, M. H. (2017). Determinan Keberhasilan E-Filing Pajak Di Indonesia: Studi Kasus Kantor Pelayanan Pajak Pratama Jakarta Tamansari Dua. Jurnal Pajak Indonesia, 1(1), $1-8$.

Arifin, S. B., \& Syafii, I. (2019). Penerapan E-Filing, E-Billing Dan Pemeriksaan Pajak Terhadap Kepatuhan Wajib Pajak Orang Pribadi Di Kpp Pratama Medan Polonia. JURNAL AKUNTANSI DAN BISNIS: Jurnal Program Studi Akuntansi, 5(1), 9. https://doi.org/10.31289/jab.v5i1.1979

Budileksmana, A. (2001). Pemeriksaan Pajak Sebagai Upaya Untuk Mendorong Kepatuhan Wajib Pajak. Jurnal Akuntansi Dan Investasi, 2(1), 56-74.

Kementerian Keuangan Republik Indonesia. (2020). Buku II Nota Keuangan beserta Rancangan Anggaran Pendapatan dan Belanja Negara Tahun Anggaran 2020.

Pratama, R. A., \& Mulyani, E. (2019). Pengaruh Kualitas Pelayanan Petugas Pajak, Sanksi Perpajakan, Dan Biaya Kepatuhan Pajak Terhadap Kepatuhan Wajib Pajak UMKM Di Kota Padang. Jurnal Eksplorasi Akuntansi, 1(3), 1293-1306. Retrieved from http://jea.ppj.unp.ac.id/index.php/jea/article/view/143

Rara Susmita, P., \& Supadmi, N. (2016). Pengaruh Kualitas Pelayanan, Sanksi Perpajakan, Biaya Kepatuhan Pajak, Dan Penerapan E-Filing Pada Kepatuhan Wajib Pajak. E-Jurnal Akuntansi, 14(2), 1239-1269.

Suharsono, A. (2018). E-SPT dan E-Filing dari Perspektif Undang-Undang. Simposium Nasional Keuangan Negara E-SPT, 336-354.

Tumuli, A., Sondakh, J., \& Wokas, H. (2016). Analisis Penerapan E-Spt Dan E-Filing Dalam Upaya Peningkatan Kepatuhan Wajib Pajak (Studi Kasus Di Kantor Pelayanan Pajak Pratama Manado). Jurnal Riset Ekonomi, Manajemen, Bisnis Dan Akuntansi, 4(3), 131073. 